\title{
THE INFLUENCE OF INFORMATION ON TRADING BEHAVIOR WITH PERSONALITY TRAITS AS MODERATION VARIABLE FOR STOCK TRADERS
}

\author{
Ronaldo Susanto ${ }^{1}$, Mariana Ing Malelak ${ }^{2}$ \\ 1,2 Finance and Investment Program, Faculty of Business and Economics, Petra Christian University \\ Jl. Siwalankerto 121-131, Surabaya \\ E-mail: 1m34415015@john.petra.ac.id; ${ }^{2 m a r i a n a . i n g @ p e t r a . a c . i d ~}$
}

\begin{abstract}
The development of investment in Indonesia has increased rapidly over the past few years. One of the key factors affecting stock traders' trading behavior is information. Information that was previously difficult to obtain by investors became easily obtained due to technological developments. In addition to information, the characteristics of traders also influence their trading behavior. The population used in this study is the entire citizen of Surabaya, and the sample of this study is stock traders who have a minimum of 1-year trading experience. Data analysis is done by using Partial Least Square with Smart PLS 3.0. The result of this study is that information has a significant effect on trading behavior, while neuroticism, extraversion, openness, agreeableness, and conscientiousness do not moderate the effect of information on trading behavior significantly.
\end{abstract}

Keywords: Investment, Trading, Stocks, Information, Trading Behavior, Trading Frequency, Personality Traits.

\section{INTRODUCTION}

An investment is an activity of purchasing an item or asset with the hope that in the future, the item or asset will gain again or increase in value (Subandi \& Basana, 2020). Investments can provide investors with additional income, and many people make investment their main source of income. Indonesia is one of the developing countries that has had stable economic development over the past ten years (Kominfo, 2017). Investment in Indonesia is also growing rapidly. Examples of stock investment and stock trading activities (trading) also become easier.

Before investing, an investor must determine the investment instrument that will be used. Different investment instruments can have different levels of return and risk. Investment instruments can be divided into two, namely tangible assets and intangible assets. In Indonesia, the most popular investment instruments are tangible assets, namely property and gold (Setiawan, 2017). On the other hand, an alternative investment instrument is more accessible for the public to reach and generate higher returns than gold and property, namely investing in the capital or stock market.

Some of the advantages of investing in the capital market are that the capital market is an investment instrument that can accommodate all types of risk profiles that potential investors may have, from riskaverse to risk-taker. In addition, stocks are assets that have high liquidity. Generally, investors only need between 1 to 3 working days to withdraw their invested funds. There are two types of people who buy stocks, namely people who buy stocks to invest or are called investors, and people who buy certain shares with the aim of selling those shares for profit in the form of capital gains are called traders. The behavior of trading can be measured using trading frequency (Abreu and Mendez, 2012). The frequency of tradespersons will directly affect their profit or loss in the capital market.

Information is one of the main factors affecting a trader's profit in investing in the capital market. In this study, information is divided into 2, namely, the amount and source of information. The results of information can be seen through the frequency with which a person gets information, while the sources of information can be divided into 3, namely, financial advice, word of mouth communication, and specialized press. The results of the pre-survey conducted to strengthen the basis of this research prove that different sources of information can have varying effects on how traders receive information. Different sources of information will have a different impact on the behavior of a trader. A more reliable source of information will make traders more often trade and vice versa. 
Apart from information, profits are trading also influenced by a person's psychological factors (personality traits). Based on the pre-survey that has been distributed, it was found that as many as $65 \%$ of respondents (13 people) bought or sold stocks based on their psychological factors. This is consistent with the theory of $\mathrm{CH}$ Chang (2008) regarding the existence of irrational investors who act contrary to traditional financial theory. The traditional financial theory believes that investors or traders will take all their actions rationally and according to market efficiency. One of the most dominant psychological factors in a person's personality traits. According to McCrae and Costa (2008), personality traits can be divided into five, namely, Neuroticism, Extraversion, Openness, Agreeableness, and Conscientiousness. What is the difference between each individual lies in how dominant one of their personality traits is compared to other personality traits.

Personality traits of traders will influence the decisions and actions they take. Different actions will result in advantages trading in different decisions. Trading that is influenced by these psychological factors will affect the profits or losses they will get on the capital market. Thus, we can conclude that the benefit of a trader in the stock market is influenced by the frequency of a trader's trade in the stock market (Tauni et al., 2017). The frequency of trading is influenced by the information obtained. A trader is willing to trade information only when he feels that the information is true and reliable. The amount and source of information play an important role in building trust in traders' information. This trust is also influenced by the characteristics of the trader. Different characteristics can result in different assessments of information from certain sources and in certain amounts. In this study, the researcher wanted to examine the effect of information on a trader's trading behavior by using the five personality traits as moderating variables.

\section{LITERATURE REVIEW}

Theory Difference of opinion proposed by Miller (1977) provides a theoretical explanation that can help researchers connect information and behavior of trading a stock trader. Theories about the behavior of traders in a world full of uncertainty have long been written by some researchers as Sharpe in 1964 and Lintner in 1965. However, in that study, it was assumed that all investor/trader has the same calculations about expected return and the possible return resulting from. However, given the difficulty of calculating the return and risk of an asset and how unpredictable the future is, it is difficult to imagine that all investors/traders will be able to produce the same results (Miller, 1977).

Information is one of the keys to making rational financial decisions. Previous research has found that the more often a trader gets information, the more often they will trade stocks (Abreu and Mendes, 2012). One explanation for this is that the more traders get the same information, the more likely they are to believe the information to be true. Traders will also expect a return greater than the effort and costs incurred in obtaining this information. In one study, Fréchette et al. (2014) looked at the role of the Big Five Personality in the selection of information made by traders when they are faced with uncertainty. They found that their characteristics would determine the type of information they would collect in advance. This information will affect their trading behavior.

Financial advice is a recommendation regarding investment decisions provided by investment experts. According to Abreu and Mendez (2012), financial advice will have an impact on more rational investment decisions and ultimately frequency trading greater. Word Mouth Communication is information that comes from friends, colleagues, family, or other social interactions. Ivković and Weisbenner (2007) argue that Word of Mouth Communication is a way that can influence financial decisions because it tends to reduce information retrieval costs by relying on social interactions. Specialized Press is information obtained from financial reports or the internet regarding data or information relating to the capital market. This information is obtained by the trader himself.

Personality traits are always associated with the characteristics and behavior patterns of an individual. According to Robbins and Judge (2012), a person's personality traits will shape their behavior. Personality traits can be categorized into five different types called the Big Five Personality (Robbins and Judge, 2012), namely, Neuroticism, Extraversion, Openness, Agreeableness, and Conscientiousness. Neuroticism talks about the influence and control of emotions. A person with a level of neuroticism high is nervous, sensitive, tense, and anxious. Extraversion is a personality that measures a person's comfort 
level when they interact with other individuals. This dimension has a personality that likes to develop relationships, is assertive, and easy to socialize with. Openness is a personality that classifies individuals based on their scope of interest and interest in new things. This dimension is very open, curious, and creative. Individuals who have this personality are more open, flexible, and easy to adapt to new things. Agreeableness is a personality that measures an individual's tendency to obey other individuals. This dimension refers to people who believe in others, are easy to work with, are friendly, have a submissive personality, avoid conflict, and tend to follow others. Conscientiousness is a measure of trust. It refers to individuals who are persistent, careful, determined, organized, and reliable. Individuals with this trait tend to be disciplined.

A trader is someone who buys shares at a certain number and price with the hope of selling them for a short period of time to get capital gains (Brennan, 2010). According to Brealey et al. (2001), the time period can be divided into two, namely, long term and short term. The long-term ranges from a minimum of 5 years while the short term is less than one year. A person's trading behavior is measured using trading frequency (Abreu and Mendez, 2012). Graham et al. (2009) found that traders who feel competent Willmore trade. This is because the frequency of a trader to trade will have an impact on their profits (Tauni et al., 2017).

Individuals with high levels of neuroticism tend to be sensitive to external stimuli in their environment. Anxiety will increase their level of nervousness which will increase their fear of uncertain situations. Even if they get more information for their buying and selling decisions, they will still feel afraid and doubtful about the decision. Information from investment experts is considered to be able to overcome their fear of uncertainty in the capital market. They think that the investment strategy provided by experts can be a solution to their fears and worries. Information that comes from financial advice makes them do more trading. On the other hand, information from word-of-mouth communication is considered dubious information. The doubts held by traders with personality traits are neuroticism, not enough. They also doubt the information obtained from the results of their own analysis (Tauni et al., 2017). This makes them less likely to trade when the information they get comes from word-of-mouth communication and the specialized press.

Because they preferred preferring others as sources of information, the trader with the type of extraversion uses information financial advice to learn and act in the market (Heinström, 2003). Therefore, information that comes from financial advice makes trader this type of trade more. Apart from financial advice, trader this type of also gets the same influence from word-of-mouth communication information. Although seeking and obtaining information on their own is a less attractive idea for traders with extraversion personality types, it does not mean that they refuse to obtain information through their own efforts. Therefore, although contrary to his personality trait, which has high social needs, the specialized press makes make traders with personality traits extraversion more trades. Individuals with personalities openness will first check and confirm the information they get (Brookfield, 1987). They will also look for alternative solutions to a problem (Brookfield, 1987). Investment expert analysis or financial advice is considered reliable information because it is the result of an analysis of a person with sufficient competence (Anggala \& Basana, 2020). Although they have a tendency to choose other people as sources of information, information obtained from social interactions is considered less reliable. Even though the information is not sourced from other people, the specialized press also makes them trade more.

Individuals with personalities agreeableness tend to be trustworthy, understanding, and seek harmony with others (McCrae and Costa, 2008). As traders, they also tend to follow the wishes of others more and less trust in their own judgments (Cloninger et al., 1994). In order to maintain social harmony, they tend to trust information from other people to make trades. Therefore, increasing the amount of information will increase the frequency of trading for traders with personalities agreeableness. When they get information from experts (financial advice), they feel very confident in that information. This makes them trade more when the information they get comes from financial advice and word-of-mouth communication. The analysis results produced by traders with personalities agreeableness usually tend to be similar to the analysis results of traders. The results of the information sourced from the specialized press are then trusted and, in the end, make traders with personality agreeableness this do more trading. 
Conscientiousness is a personality that reflects an individual with a personality that is efficient, organized, and responsible (Costa and McCrae, 1992). As traders, they are able to obtain high-quality information and relevant information (Heinström, 2003). This makes them more often trade stocks. Although information sourced from financial advice (investment experts) is more reliable information when compared to information sourced from word-of-mouth communication, they still choose to rely on themselves (Tauni et al., 2017). Therefore, traders' stock with characteristics conscientiousness tends to trade less when they get information sourced from financial advice and word-of-mouth communication. Meanwhile, they trade more when the information they get comes from themselves or the specialized press.

\section{METHODOLOGY}

This research is an associative type of research. According to Sugiyono (2003), associative research is research that aims to determine the effect or relationship between two or more variables. The research approach used is quantitative research methods, namely research on a particular sample and population by using data in the form of numbers and statistics to test the predetermined hypothesis (Sugiyono, 2018). This study examines the effect of information on trading behavior of stock trader in Surabaya with personality traits as moderating variable. The population used in this study were all people in the city of Surabaya. The sampling technique in this study was purposive sampling. The sample of this study was 100 respondents using the following sampling criteria:
a. Residing in Surabaya.
b. Have bought and sold shares.
c. Is a stock trader.
d. Have at least 1 year of experience in activities trading stock.

This research uses primary data, which is data taken directly from the first source, such as an individual or related person. The source of this research data was obtained by distributing questionnaires to respondents that had been adjusted according to the sample criteria. The questionnaires were distributed using a closed questionnaire method. A closed questionnaire is a questionnaire where respondents are asked to answer questions by choosing one of the answer options that have been provided previously. The answer choices provided can be in the form of multiple-choice or Likert 5-point scale.

In this study, data processing was carried out with the help of the programs Smart PLS 3.0 (SPLS) and Microsoft Excel 2017 using the following data analysis techniques.

1. Tabulating data to compile data that has been collected into tables. Data tabulation is done in order to make it easier to organize the data that will be presented for later analysis.

2. Perform descriptive statistics on the data used in the study in order to see the characteristics of all the data to be analyzed.

3. Perform analysis Partial Least Square (PLS) using the model Structural Equation Modeling (SEM). PLS analysis is carried out in order to answer the problem formulation. PLS analysis consists of several steps, namely,

1. designing the inner and outer model.

2. Making a path diagram and building it into a system of equations.

3. Estimating test

4. Conducting an evaluation of the results of the goodness of fit

5. Conducting hypothesis testing

\section{ANALYSIS AND DISCUSSION}

Based on the results of the questionnaire, it can be seen that the majority of respondents are male respondents, as many as 72 people, and women as many as 28 people. In the age variable, there are 58 respondents aged between 25 and 40 years, 28 respondents aged 41 to 60 years, 13 respondents aged under 25 years, and one respondent aged over 61 years. In the variable of marital status, 53 respondents were married, and 47 respondents were not married. Meanwhile, 64 respondents have an undergraduate degree in the education variable, 17 respondents have a high school education, 15 respondents have a master's degree, three respondents have a diploma degree, and one respondent has a doctoral education. 
Table 1. Descriptive Statistics

\begin{tabular}{|c|c|c|c|c|c|c|}
\hline & Min & Max & & Mean & & Std. Dev \\
\hline N1 & 2.5983 .2817 & 5 & 2.55 & & 1 & 1.104 \\
\hline N2 & 1.067 & 5 & 2.45 & & & 1 \\
\hline N3 & 1 & 5 & 3.15 & & & 1.019 \\
\hline N4 & 1 & 5 & 2.17 & & & 1.092 \\
\hline N5 & 1 & 5 & 2.67 & & & 1.074 \\
\hline E1 & 3.6075 & 5 & 3.78 & 2 & & 0.799 \\
\hline E2 & 0.921 & 5 & 3.60 & & & 1 \\
\hline E3 & 0.914 & 5 & 3.65 & & & 1 \\
\hline E4 & 1 & 5 & 3.40 & & & 1.035 \\
\hline $\mathrm{O} 1$ & 3.5721 .038 & 5 & 3.45 & & & 1 \\
\hline $\mathrm{O} 2$ & 1 & 5 & 3.59 & & & 0.805 \\
\hline $\mathrm{O} 3$ & 1 & 5 & 3.37 & & & 0.812 \\
\hline $\mathrm{O} 4$ & 2 & 5 & 3.97 & & & 0.797 \\
\hline $\mathrm{O} 5$ & 1 & 5 & 3.48 & & & 1,000 \\
\hline A1 & 1 & 5 & 2.73 & 3.085 & & 0.827 \\
\hline A2 & 1 & 5 & 2.98 & & & 0.932 \\
\hline A3 & 1 & 5 & 3.01 & & & 0.980 \\
\hline A4 & 1 & 5 & 3.62 & & & 0.801 \\
\hline C1 & 1 & 5 & 3.81 & 3.546 & & 0.929 \\
\hline C2 & 1 & 5 & 3.77 & & & 0.930 \\
\hline C3 & 1 & 5 & 2.95 & & & 0.999 \\
\hline C4 & 1 & 5 & 3.47 & & & 1.029 \\
\hline C5 & 0.851 & 5 & 3.73 & & & 2 \\
\hline TRADE & 1.376 & 5 & $\begin{array}{l}3.19 \\
3.19\end{array}$ & & 3.19 & 1 \\
\hline J.INFO & 3.70253 .7025 & 5 & 4.22 & & 1 & 1.142 \\
\hline ADVICE & 1 & 5 & 3,78 & & & 1,454 \\
\hline WOM & 1 & 5 & 3.63 & & & 1.482 \\
\hline PRESS & 1 & 5 & 3,18 & & & 1,546 \\
\hline
\end{tabular}

\section{Outer Model}

Test The results of the test convergent validity can be seen through the value of the loading factor of each indicator. If it is found that the loading factor value of each indicator is above 0.5 , the indicator of a variable is declared valid.

Table 2. Loading Factor

\begin{tabular}{ccc}
\hline Indicator & Loading factor & Specification \\
\hline N2 & 0.814 & Valid \\
N3 & 0.859 & Valid \\
N5 & 0.709 & Valid \\
E1 & 0.989 & Valid \\
E3 & .642 & Valid \\
E4 & 0.527 & Valid \\
O1 & 0.830 & Valid \\
O4 & 0.866 & Valid \\
O5 & 0.776 & Valid \\
A1 & 0.773 & Valid \\
A2 & 0,833 & Valid \\
A3 & 0.725 & Valid \\
A4 & 0.905 & Valid \\
C1 & 0.508 & Valid \\
C2 & 0.538 & valid \\
C3 & 0.703 & valid \\
C4 & 0.613 & valid \\
C5 & 0.700 & valid \\
JINFO & 0.872 & valid \\
ADVICE & 0.824 & valid \\
WOM & 0.800 & valid \\
PRESS & 0.728 & valid \\
\hline
\end{tabular}


In the first test, it was found that all the indicators in the variable agreeableness, conscientiousness and the information are valid. Meanwhile, several indicators on the variables were neuroticism, extraversion, and openness not yet valid. So that the elimination of indicators N4, E2, and O2. After that, I retested it again, and it looks like in Table 4.2 that all indicators in the variable extraversion are valid. Because there are still indicators that are not yet valid on the variables neuroticism and openness, elimination is carried out on the $\mathrm{N} 1$ and $\mathrm{O} 3$ indicators and retesting. After the third test, all indicators on the variables neuroticism and openness were valid. The results of the test discriminant validity can be done by looking at the results of the Average Variance Extracted or AVE value. The AVE value required for a variable to be declared valid is above 0.5 .

Table 3. Discriminant Validity

\begin{tabular}{lcc}
\hline \multicolumn{1}{c}{ Variable } & AVE & Information \\
\hline Neuroticism & 0.634 & Valid \\
Extraversion & 0.556 & Valid \\
Openness & 0.681 & Valid \\
Agreeableness & 0.659 & Valid \\
Conscientiousness & 0.382 & Valid \\
Information & 0.653 & Valid \\
\hline
\end{tabular}

At the time of the first test, all variables except conscientiousness were valid. Then the $\mathrm{C} 1$ indicator was eliminated. However, after retesting, the AVE variable of conscientiousness was still not valid. So that the elimination of another indicator, namely $\mathrm{C} 2$. In the third test, the AVE of all research variables can be declared valid because the AVE value is above 0.5 . The results of the test composite reliability can be seen through Cronbach's Alpha value. The Cronbach's Alpha required value is above 0.6.

Table 4. Cronbach's Alpha

\begin{tabular}{lcc}
\hline \multicolumn{1}{c}{ Variable } & Cronbach's Alpha & Description \\
\hline Neuroticism & 0,729 & Valid \\
Extraversion & 0.856 & Valid \\
Openness & 0.774 & Valid \\
Agreeableness & 0,848 & Valid \\
Conscientiousness & 0.659 & Valid \\
Information & 0.821 & Valid \\
\hline
\end{tabular}

\section{Inner Model Test Results}

Based on the test results of R-Square that has been done, the resulting value of R-Square as follows:

Table 5. Results of R-Square

\begin{tabular}{cc}
\hline Dependent variable & Value R-square \\
\hline frequency Trading & 0.500 \\
\hline
\end{tabular}

Based on Table 4.5 was found to R-square of the frequency-dependent variable trading amounted to 0.500 . This means that as much as $50 \%$ of frequency is trading a traders influenced by the variables used in this study. Based on the results of the t-test that has been carried out in this study, the resulting $t-$ test values are as follows:

Table 6. T-Test Results

\begin{tabular}{|c|c|c|c|c|}
\hline No & Information & T Calculate & T Table & Conclusion \\
\hline 1 & Information affects the behavior of trading a stock trader in Surabaya. & 9,171 & 1,96 & Significant \\
\hline 2 & $\begin{array}{l}\text { Neuroticism moderates the influence of information on the behavior of } \\
\text { trading a stock trader in Surabaya. }\end{array}$ & 1.059 & 1.96 & Not Significant \\
\hline 3 & $\begin{array}{l}\text { Extraversion moderates the effect of information on the behavior of } \\
\text { trading a stock trader in Surabaya. }\end{array}$ & 0.993 & 1.96 & icant \\
\hline 4 & $\begin{array}{l}\text { Openness moderates the effect of information on the behavior of } \\
\text { trading a stock trader in Surabaya. }\end{array}$ & 0.887 & 1.96 & $N$ \\
\hline 5 & $\begin{array}{l}\text { Agreeableness moderates the effect of information on the behavior of } \\
\text { trading a stock trader in Surabaya. }\end{array}$ & 0.466 & 1.96 & Not Significant \\
\hline 6 & $\begin{array}{l}\text { Conscientiousness moderates the effect of information on the } \\
\text { behavior of trading a stock trader in Surabaya. }\end{array}$ & 0.115 & 1.96 & Not Significant \\
\hline
\end{tabular}


Hypothesis testing is done by looking at the results of the t-test. The criterion for rejection of $\mathrm{H}_{0}$ is if the calculated $t$ value is greater than the $t$ table. The t table used was 1.96 at the $5 \%$ significance level.

Based on table 4.6, it is found that information has a significant effect on a trader's trading behavior. This can be seen through the $t$ value and t table, namely 9.171>1.96. Meanwhile, neuroticism, extraversion, openness, agreeableness, and conscientiousness did not significantly moderate the effect of information on trading behavior a traders.

\section{Discussion}

The partial test results of the interaction of moderating variables on trading behavior found that information had a significant effect on trading behavior, and neuroticism, extraversion, openness, agreeableness, and conscientiousness did not significantly moderate the effect of information on trading behavior.

These results are consistent with research conducted by Tauni et al. (2017) that neuroticism, extraversion, openness, agreeableness, and conscientiousness do not significantly moderate the effect of information on a trader's trading behavior.

In addition, it can be seen that the average answer for the indicator personality traits is 3.2817 , which of these answer choices is close to choose 3, which is neutral. A neutral answer choice can make the test results less accurate. The average value of 3.2817 shows that the data generated from this questionnaire cannot provide an accurate picture of the effect of personality traits as a moderating variable.

The average choice of answers to 3.2817 above can be caused by a lack of selection of the sample carried out and the imbalance of the sample used in the study. An unbalanced sample means a sample that is not representative of a study. Unrepresentative samples will give inaccurate research results (Sugiyono, 2018). Which is better in order to get more accurate research results, researchers can use a sample with a balanced number of dominant personality traits so that they can produce a representative sample.

Based on the respondent's answer data, the most common personality trait in this study was openness with 45 respondents, followed by extraversion with 43 respondents. There were 27 respondents with personality traits conscientiousness, 15 respondents with personality traits neuroticism, and eight respondents with agreeableness. Overall, there are 137 dominant personality traits for 100 respondents.

Research sources find that respondents can also provide an explanation of the results of this study. The majority of the samples obtained by researchers were generated through distributing questionnaires to chat groups on the applications telegram, Facebook, Line, and WhatsApp. This could explain why individuals with dominant personalities, extraversion, and openness, dominate this research. Someone with personality extraversion has a high need for social interaction. This makes them less likely to participate in group chat. Individuals with personalities openness can sort out information that they can use and information that cannot be trusted.

\section{CONCLUSIONS AND RECOMMENDATIONS}

Based on the results of this study, the following conclusions can be drawn:

1. Information has a significant effect on trading behavior for stock traders in Surabaya.

2. The information does not have a significant effect on trading behavior for stock traders with neuroticism in Surabaya.

3. The information does not have a significant effect on trading behavior for stock traders with extraversion personality in Surabaya.

4. The information does not have a significant effect on trading behavior for stock traders with openness personality in Surabaya.

5. The information does not have a significant effect on trading behavior for stock traders with agreeableness personality in Surabaya.

6. The information does not have a significant effect on trading behavior for stock traders with conscientiousness personality in Surabaya. 
Based on the results of this study, suggestions from researchers for further research are as follows:

1. Use other variables that may affect trading a trader's behavior such as the amount of investment value or the amount of information costs traders.

2. Perform sample selection and eliminate samples with too many answer choices 3.

3. Samples need to be distinguished for each personality trait so that the data used is representative, using 500 respondents, with 100 respondents for each dominant personality trait.

\section{REFERENCES}

Abreu, M. \& Mendes, V. (2012). Information, Overconfidence and Trading: Do The Sources of Information Matter? Journal of Economic Psychology, 33 (4), 868-881.

Anggala, A. \& Basana, S. R. (2020). Pengaruh Related Party Transaction Terhadap Nilai Perusahaan. International Journal of Financial and Investment Studies (IJFIS), 1(1), 42-52. https://doi.org/10.9744/ijfis.1.1.42-52

Brennan, T. (2010, August 20). The Difference Between Investing \& Trading. Retrieved from https://www.cnbc.com/ en/38788780

Brookfield, S. (1987). Developing Critical Thinkers. Milton Keynes. England: Open University Press.

$\mathrm{CH}$ Chang. (2008). The Impact of Behavioral Pitfalls on Investors' Decisions: The Disposition Effect in The Taiwanese Warrant Market. Social Behavior and Personality, 617-634.

Cloninger, CR, Przybeck, TR \& Svrakic, DM (1994). The Temperament and Character Inventory (TCI): A Guide To Its Development and Use. Center for Psychobiology of Personality. St Louis. MO: Washington University.

Fréchette, GR, Schotter, A. \& Treviño, I. (2014). Personality, Information Acquisition and Choice Under Uncertainty: An Experimental Study. Economic Inquiry.

Heinström, J. (2003). Five Personality Dimensions and Their Influence on Information Behaviour. Information Research, 9(1), 1-9.

Ivković, Z. \& Weisbenner, S. (2007). Information Diffusion Effects in Individual Investors' Common Stock Purchases: Covet Thy Neighbors' Investment Choices. Review of Financial Studies, 20(4), 1327-1357.

Kominfo. (2017). Pertumbuhan Ekonomi Indonesia Stabil 10 Tahun Terakhir. Retrieved from https://kominfo.go.id/ content/detail/11635/pertumbuhan-ekonomi-indonesia-stabil-10-tahun-terakhir/0/berita_satker

Mayfield, C., Perdue, G. \& Wooten, K. (2008). Investment Management and Personality Type. Financial Services Review, 17(3), 219-236.

McCrae, RR \& Costa, PT (2008). Empirical and Theoretical Status of The Five-Factor Model of Personality Traits. in Boyle, GJ, Matthews, G. \& Saklofske, DH Handbook of Personality Theory and Assessment: Personality Measurement and Testing Vol. 1. Sage. London. 273-294.

Miller, EM (1977). Risk, Uncertainty, and Divergence of Opinion. The Journal of Finance, 32(4), 1151-1168.

Robbins, SP \& Judge, TA (2012). Organizational Behavior (15th Ed.). NJ: Pearson Education, Inc.

Setiawan, SRD (2017, November 24). Jenis Investasi Ini Paling Diincar Investor Indonesia. Retrieved from https://ekonomi.kompas.com/read/2017/11/24/123000926/jenis-investasi-ini-paling-diincar-investor-indonesia

Subandi, J.R. \& Basana, S.R. (2021). The effect of salience and disposition effect on stock investment decisions on investors in Surabaya. International Journal of Financial and Investment Studies (IJFIS), 1(2), 77-84. Retrieved from https://ojs.petra.ac.id/ijfis/index.php/ijfis/article/view/56

Sugiyono. (2003). Metode Penelitian Bisnis.Bandung. Pusat Bahasa Depdiknas.

Sugiyono. (2018). Metode Penelitian Kuantitatif, Kualitatif, Dan R\&D. Bandung: Alfabeta.

Tauni, MZ, Rao, Z., Fang, H. \& Gao, M. (2017). Does Investor Personality Moderate The Relationship Between Information Sources and Trading Behavior? Evidence from Chinese Stock Market. Managerial Finance, 43(5), 545-566.

Tauni, MZ, Rao, Z., Fang, H., Mirza, SS, Memon, ZA \& Jebran, K. (2017). Do Investor's Big Five Personality Traits Influence the Association Between Information Acquisition and Stock Trading Behavior? China Finance Review International, 7(4), 450-477. 